\title{
Assessment of space and time changes of NDVI (biomass) in Armenia's mountain ecosystems using remote sensing data
}

\author{
V.S. Muradyan, Sh.G. Asmaryan, A.K. Saghatelyan \\ Center for Ecological-Noosphere Studies NAS RA \\ Yerevan 0025, Armenia \\ E-mail:muradyan-asx@rambler.ru
}

\begin{abstract}
This study of vegetation biomass for different areas in the mountain ecosystems of Armenia was implemented for the vegetation period of 2013. The research was done based on time series of Normalized Difference Vegetation Index (NDVI) as NDVI images have been proven to be a powerful tool to monitor biomass growth during the last decade. NDVI, which can be directly calculated from Landsat satellite data, is related to vegetation canopy characteristics. This NDVI-based research of different-aspect slopes at 1850-3150 m have indicated that during vegetation period the highest biomass is detected on north facing slopes at altitudes of 2300-2400 m, and the lowest - on south facing slopes at altitudes of 2000-2100 m. High correlation coefficients between NDVI values of southwest slopes and absolute altitudes of localities are detected in April and August, whereas variation in NDVI values depending on the altitude is nonlinear.
\end{abstract}

Keywords: biomass, mountain ecosystem, NDVI, remote sensing data

\section{Introduction}

The enormous diversity of Armenia's plants is determined by complexity of its relief, various bioclimatic conditions, geographical position, peculiarities of centuries-long geological evolution of natural environment, and diversity of landscape belts. Both the current status of Armenia's economy and its development perspectives require improvement and effective management of native vegetation cover.

The country's vegetation cover represents an entity of exclusively diverse plant species widely spread throughout the South Caucasian region. The vegetation cover is highly bioactive and produces substantial reserves of biomass. Due to their high productivity and nutritional value plant communities are utilized as grasslands mainly with a stock rising purpose. In Armenia, vegetation cover studies and mapping were initiated and implemented by renown Armenian scientists (Aghababian, 1959; Maghakian, 1941) as far back as in 1940-50s. In recent years, large-scale investigations were implemented aimed at assessing and studying biomass generated from Armenia's native grasslands and peculiarities of time and space changes in them (Ziroyan, 2008; Mezhunts, 2005; Narinian, 1966). In different vegetation belts, relationships between biomass and height of a locality were studied. For instance, in respect of meadow steppe associations a direct relationship is established between aboveground biomass and height $(\mathrm{r}=0.43-0.54)$ as well as grass stand density $(\mathrm{r}=0.78-0.82)$. The studies were implemented mostly by the accepted field research methods, however application of advanced geographical technologies emphasizing remote sensing data is very desirable and helpful.

Application of remote sensing data that encompass vast areas and reflect natural interrelations, allows exclusion of random or short-term changes, focusing thus on the processes of transformation of ecological state of the ecosystem under observation (Trifonova et al., 2005; Kronberg, 1988).

Since the advent of remote sensing technologies many researchers have studied the potential of remote sensing devices to monitor green vegetation. They developed robust and significant 
relationships between sensor derived measurements and ground truth vegetation measurements such as biophysical and biochemical variables. Remote sensing optical tools as a rule operate onboard either aircrafts or satellites, and are used for describing green vegetation features. While having the advantage of speed, surveying using space and airborne sensors involves extremely expensive equipment, complex processing, and is affected by frequent cloud cover, when imaging is useless. To overcome these problems, ground or field based optical sensing tools (or proximal sensors) are being developed with some already commercially available. These have been used to evaluate vegetation and field crops characteristics. In addition, proximal sensors provide realtime information for decision making (Hatfield et al., 2008; Hunt et al., 2003).

Landsat satellite data are the most widely used data type for land cover mapping and have provided Earth observation data to meet a wide range of information needs since 1972 (Williams et al., 2006). Change detection can be performed using Vegetation index (Singh, 1989). Vegetation index differencing is often regarded as an effective method to enhance the difference among spectral features (Lu et al., 2005). NDVI is often used to monitor vegetation dynamics (Zhou et al., 2001).

This study was designed to monitor the development of vegetation biomass by remote sensing methods for Armenia's different areas in vegetation period. Time series of NDVI images were used for the study, as NDVI was proven to be a powerful tool to monitor biomass growth during the last decade (Minamiguchi, 2005). NDVI, which can be directly calculated from satellite data, is related to vegetation canopy characteristics such as biomass and percentage of vegetation cover and is representative of plant photosynthetic efficiency and fluctuations due to changes in meteorological and environmental parameters. NDVI images allow agricultural managers to analyse vegetation conditions for all seasons from NDVI maps, NDVI curves and figures and forecast major variations in productivity and potential harvest (Biard, Lepoutre, 2005).

Spectral reflectance in the red and near infrared (NIR) regions of the spectrum has been shown to be directly related to ground forage biomass. Mathematical combinations of red and NIR spectral wavebands constituting vegetative indices take advantage of plant reflectance in both regions of the spectrum (Lusch, 1999). Indices such as NIR:red ratio and NDVI take advantage of reflectance in both NIR and red regions reducing measurement variability due to soil type, sunlight intensity and angle of sunlight incidence (Lusch, 1999). NDVI is correlated with biomass when the leaf area index (LAI) is less than 3 (Flynn et al., 2008; Serrano et al., 2000). However, NDVI alone showed very weak relationship with biomass in corn and mixed tall grass prairie, that can be improved by combination with canopy or plant height (Freeman et al., 2007; Olson, Cochran, 1998).

\section{Materials and methods}

This research covers Armenia's mountain ecosystems located at altitudes of 1850$3100 \mathrm{~m}$ and was implemented in vegetation period of 2013 using the obtained satellite images. 
Armenia $\left(40^{\circ} 6^{\prime} 0^{\prime \prime} \mathrm{N}, 45^{\circ} 3^{\prime} 0^{\prime \prime} \mathrm{E}\right)$ is located in the Southern Caucasus, the region between the Black Sea and the Caspian Sea. About half of Armenia's area of approximately $29,800 \mathrm{~km}^{2}$ has an elevation of at least 2,000 m, and only $3 \%$ of the country lies below $650 \mathrm{~m}$. The climate is highland continental: hot summers and cold winters. Temperatures in Armenia generally depend upon elevation.

Armenia's vegetation cover is characterized by sharply pronounced vertical zonation and semi-desert to alpine vegetation. Our studies cover mountain steppe, mountain meadow steppe, subalpine meadow and alpine meadow ecosystems. Pastures lying at different heights and in different vegetation belts differ not only in their productivity and biomass, but also in species composition (Table 1) (CARMAC...; Mezhunts et al., 2005).

Table 1. Pasture productivity and plant formations per landscape belt

\begin{tabular}{|l|c|c|c|}
\hline \multicolumn{1}{|c|}{ Belts } & Area, $\boldsymbol{h a}$ & $\begin{array}{c}\text { Dry biomass, } \\
\boldsymbol{D B}, \boldsymbol{k g} \boldsymbol{h a}\end{array}$ & Formation \\
\hline Mountain steppe & $1800-2200$ & 2300 & Grain forbs \\
\hline Mountain meadow steppe & $2200-2500$ & 2100 & Legume forbs \\
\hline Subalpine mountain meadow & $2500-2900$ & 2550 & $\begin{array}{c}\text { Grain forbs, } \\
\text { tall growing grasses }\end{array}$ \\
\hline Alpine mountain meadow & $2900-3400$ & 1520 & $\begin{array}{c}\text { Alpine meadows } \\
\text { and carpets }\end{array}$ \\
\hline
\end{tabular}

The study region's pastures are dominated by plant species belonging to basic genera of grasses, forbs and legumes such as Poa bulbosa, Poa alpina, Hordeum crinitum, Aegilops cylindrica, Agropyrum trichophorum, Festuca sulcata, Festuca ovina.

Field studies indicate that productivity of plant communities and their dominants significantly change in period of vegetation and that productivity varies rather widely from year to year. In most cases such changes have a character of cyclic fluctuations and are determined by ecotonic and climatic conditions and biological peculiarities of species. A seasonal biomass accumulation process is characterized by an intense start in spring and a gradual drop in summer. The size of aboveground biomass in the intense growth period is rather closely associated with edaphic factors (Ziroyan, 2008).

Landsat OLI images obtained in 2013 were selected for the analysis in this research (Table 2) (https://lta.cr.usgs.gov/L8).

Table 2. Satellite image information for data acquisitions

\begin{tabular}{|lllll|}
\hline \multicolumn{1}{|c}{ Imagery date } & Spatial resolution & Satellite/sensor & No. of bands & Format \\
\hline April 24, 2013 & $30 \mathrm{~m}$ & Landsat-8 OLI & 10 & GeoTIFF \\
May 05, 2013 & $30 \mathrm{~m}$ & Landsat-8 OLI & 10 & GeoTIFF \\
June 15, 2013 & $30 \mathrm{~m}$ & Landsat-8 OLI & 10 & GeoTIFF \\
July 01, 2013 & $30 \mathrm{~m}$ & Landsat-8 OLI & 10 & GeoTIFF \\
August 18, 2013 & $30 \mathrm{~m}$ & Landsat-8 OLI & 10 & GeoTIFF \\
September 03, 2013 & $30 \mathrm{~m}$ & Landsat-8 OLI & 10 & GeoTIFF \\
October 21, 2013 & $30 \mathrm{~m}$ & Landsat-8 OLI & 10 & GeoTIFF \\
November 06, 2013 & $30 \mathrm{~m}$ & Landsat-8 OLI & 10 & GeoTIFF \\
\hline
\end{tabular}

All satellite data were geometrically corrected to the UTM (Universal Transverse Mercator) zone 38 projection. Radiation from the Earth's surface undergoes significant interaction with the 
atmosphere before it reaches a satellite sensor. Hence, it is essential to consider the effects of the atmosphere by applying a reliable and efficient atmospheric correction during pre-processing of digital data (Hadjimitsis et al., 2010). The most recent addition to empirical methods requiring no ground reference information is the QUAC (quick atmospheric correction) method. QUAC is a VNIR (visible near infrared) through SWIR (shortwave infrared) atmospheric correction method for multispectral and hyperspectral imagery. Unlike other first-principles atmospheric correction methods, it determines atmospheric compensation parameters directly from the information contained within the scene (observed pixel spectra), without ancillary information (Bernstein et al., 2005).

Topographic correction of satellite images of mountain areas is an essential prerequisite. Topographic correction restores reflectance values of shady areas, and simultaneously approximates identical objects located in differently lit areas.

We implemented topographical correction by a NRCGIT Topocorrection utility for ENVI (http://nrcgit.ru/topocorr/). In particular, we used the Minnaert-Colby method for topographic correction as it takes into account surface inclination angles (Belsius, Weirich, 2005). As topographic correction is based not only on a satellite image, but also on a digital relief model having a spatial resolution corresponding to the image, so we used 30m-resolution SRTM (Shuttle Radar Topography Mission) data.

The NDVI is used for monitoring and assessing the vegetation (Kaufman, Tanre, 1992). In general, NDVI values range from -1.0 to 1.0 , with negative values indicating clouds and water, positive values near zero indicating bare soil, and higher positive values of NDVI ranges from sparse vegetation (0.1-0.5) to dense green vegetation (0.6 and above). After this fixed range of densities (0.7), an increase in green plant volume results in slight increase of NDVI (Milich, Weiss, 2000) (Table 3).

Table 3. Assessment of biomass and vegetation cover of ecosystem by NDVI values

\begin{tabular}{|c|c|}
\hline NDVI & Biomass and vegetation cover \\
\hline$-1-0.10$ & Bare soil or no data \\
\hline $0.11-0.20$ & Minimum biomass, very low-standing grass vegetation \\
\hline $0.21-0.30$ & Middle biomass, low-standing grass vegetation \\
\hline $0.31-0.55$ & High biomass, high-standing grass vegetation \\
\hline $0.56-0.70$ & Very high biomass, high-standing grass vegetation with random shrub vegetation \\
\hline $0.71-1.00$ & Maximum biomass, forested plots \\
\hline
\end{tabular}

The NDVI is also directly related to:

- herbaceous or total green biomass (tons/ha) for a given vegetation type;

- photosynthetic activity of vegetation;

- percentage of ground cover.

A satellite spectrometer or radiometric sensor measures and stores reflectance values for both red and NIR bands on two separate channels. NDVI is calculated by subtracting the red channel from the nearinfrared (NIR) channel and dividing their difference by the sum of the two channels (Rause et al., 1973; Kriegler et al., 1969): 


$$
\mathrm{NDVI}=(\mathrm{NIR}-\mathrm{RED}) /(\mathrm{NIR}+\mathrm{RED})
$$

where RED is the red portion of the electromagnetic spectrum $(0.6-0.7 \mu \mathrm{m})$ and NIR is the near infrared portion of the electromagnetic spectrum $(0.75-1.5 \mu \mathrm{m})$.

NDVI difference images easily track changes in the amount of biomass for a particular period relative to the historical average or a previous year (Minamiguchi, 2005). Thus the technique highlights areas with comparatively reduced or increased plant growth.

The NDVI difference image (NDVIdiff) between two time periods is calculated by subtracting the NDVI image of the earlier time period (NDVI1) from the time period of interest (NDVI2):

$$
\text { NDVIdiff }=\text { NDVI2 }- \text { NDVI1 }
$$

Based on a digital elevation model (DEM), derivative thematic slope layers and aspects using a 3D Analyst expansion moduli were obtained. ERDAS Imaging 2011 and ENVI 4.7 were used for the image processing, ArcGIS 9.3 with 3D Analyst, Spatial Analyst expansion modules were used for analysis of DEM. MS Word was used for documentation while MS Excel was used for statistical analysis by linear and nonlinear regression equations.

\section{Results and discussion}

Based on a series of Landsat OLI multi-channel images obtained in 2013, studies were done of NDVI variations in the vegetation period (April through November) on different aspects at altitudes between 1850 and $3150 \mathrm{~m}$ (steppe, meadow steppe, subalpine and alpine meadow).

Meadow steppe plant communities (2200-2500 m) are composed of species having different growth rhythms, which determines a seasonal increase in the biomass of coenoses. The grass stand is composed of lowest-productivity early spring-cycle plants and of maximal-productivity summercycle plants. In spring, the grass stand is dominated by synusia of early-spring ephemeroids. Field studies indicate that on different plots of land, the green biomass is $218-260 \mathrm{~g} / \mathrm{sq} . \mathrm{m}$ and absolutely dry $-42-50$ g/sq.m. Ephemeroids grow very rapidly after snowmelt, so in 7-10 days the aboveground biomass accumulation reaches its maximum, then starts decreasing and almost completely dries out during 3 weeks. By the beginning of June, the productivity of dry aboveground mass in clover association makes 88-110 g/sq.m (Ziroyan, 2008). In June, productivity increases rapidly reaching its maximum in mid-June, then the green mass starts decreasing again in result of the aboveground green mass die-off. Beginning early August, this process accelerates drastically.

According to remote sensing data obtained in meadow steppe belt (2200-2500 m), NDVI values registered for south facing slopes are higher than those for north facing slopes in April, October and November, during the rest of the months NDVI values for north facing slopes are higher (Fig. 1).

Among north facing slopes, the highest biomass is on 2300-2400 m high slopes, which have high NDVI values except in October and November. 


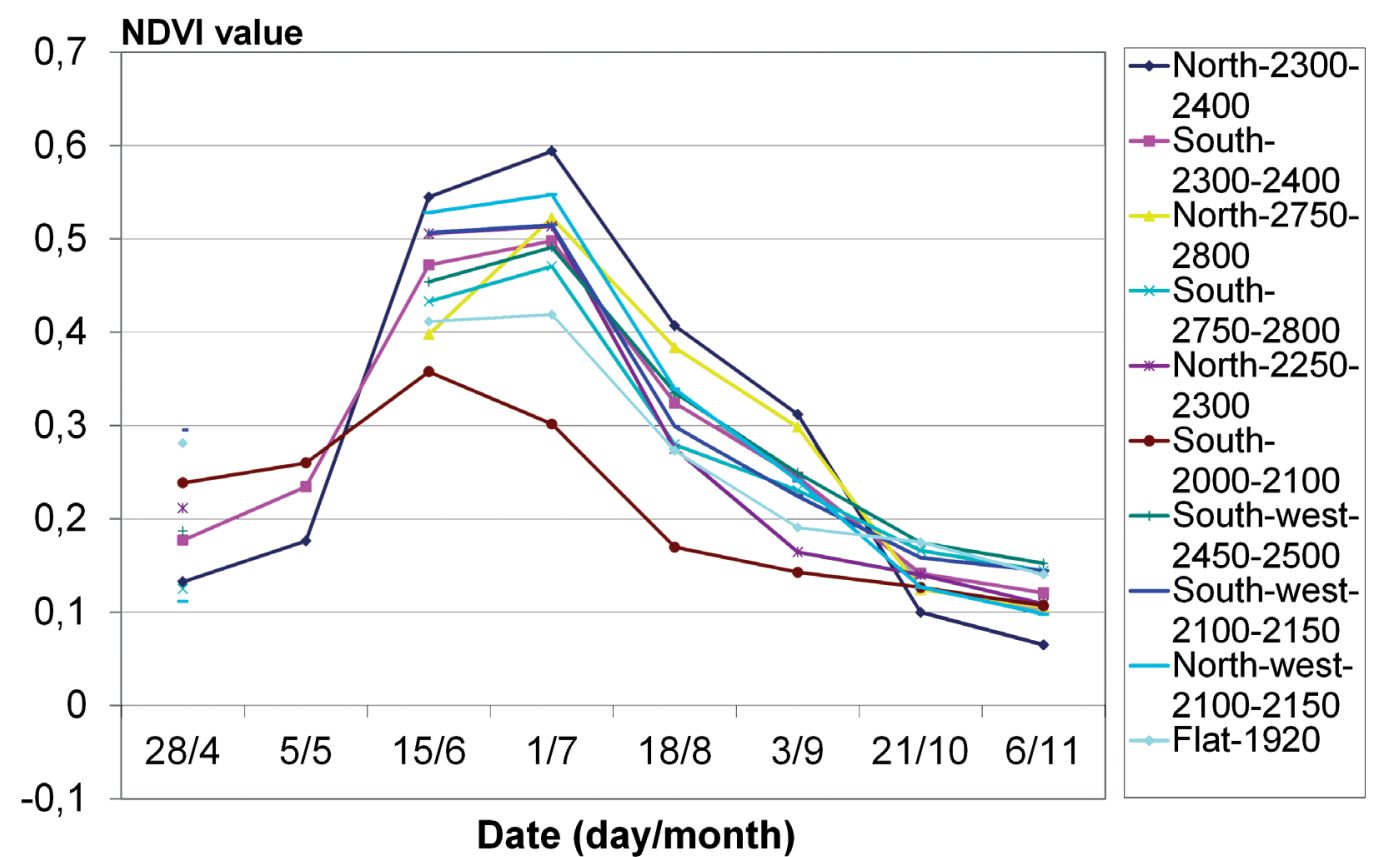

Fig. 1. Variations of averaged values of NDVI in the vegetation period on different-aspect slopes at different altitudes

Collation between different-altitude south facing slopes shows that low biomass is detected at heights of 2000-2100 and 2750-2800 m, the highest - on the southeast and south facing slopes at $2300-2400 \mathrm{~m}$.

The results obtained for meadow steppe belt from remote sensing data agree well with field data, proving NDVI useful for the studies of mountain ecosystem biomass dynamics in the vegetation period. To demonstrate time and space variations in biomass in April - October 2013, collation was done between NDVI maps of slopes with southwest aspect.

One of effective methods to register space variations of biomass within a definite period of time is to compute the difference between NDVI raster maps. This was implemented by Raster Calculator function of Spatial Analyst Tool of ArcGIS program package for raster maps of southwest mountain slopes NDVI for 2 different months. The derived NDVIdiff indices show trends in biomass variations and vegetation share in the given ecosystem according to the following scale:

$$
\begin{gathered}
\text { NDVIdiff values } \\
-1.00 \div-0.60 \\
-0.61 \div-0.20 \\
-0.21 \div 0.20 \\
0.21 \div 0.60 \\
0.61 \div 1.00
\end{gathered}
$$

\author{
Biomass variations trend \\ significantly decreasing \\ decreasing \\ no changes \\ increasing \\ significantly increasing
}

NDVIdiff maps (Fig. 2) show a considerable growth of biomass in the high altitude belt of 2800-3150 m in June, July, August and September as compared to April. In October, NDVIdiff values varied between $-0.21 \div 0.20$, i.e. almost no variations were observed in the entire area. 
Collation of NDVI values for June vs. August, September, October indicates a sharp decrease of biomass particularly in the medium-altitude (2000-2500 m) belt, which is determined by increasing temperature and decreasing amount of atmospheric precipitation in the noted months, whereas changes in low and high altitude sections are very insignificant. Certainly, drying climatic conditions are observed also in low-altitude belts, however farming activities there prevent the decrease in biomass, in fact, they boost biomass increase.

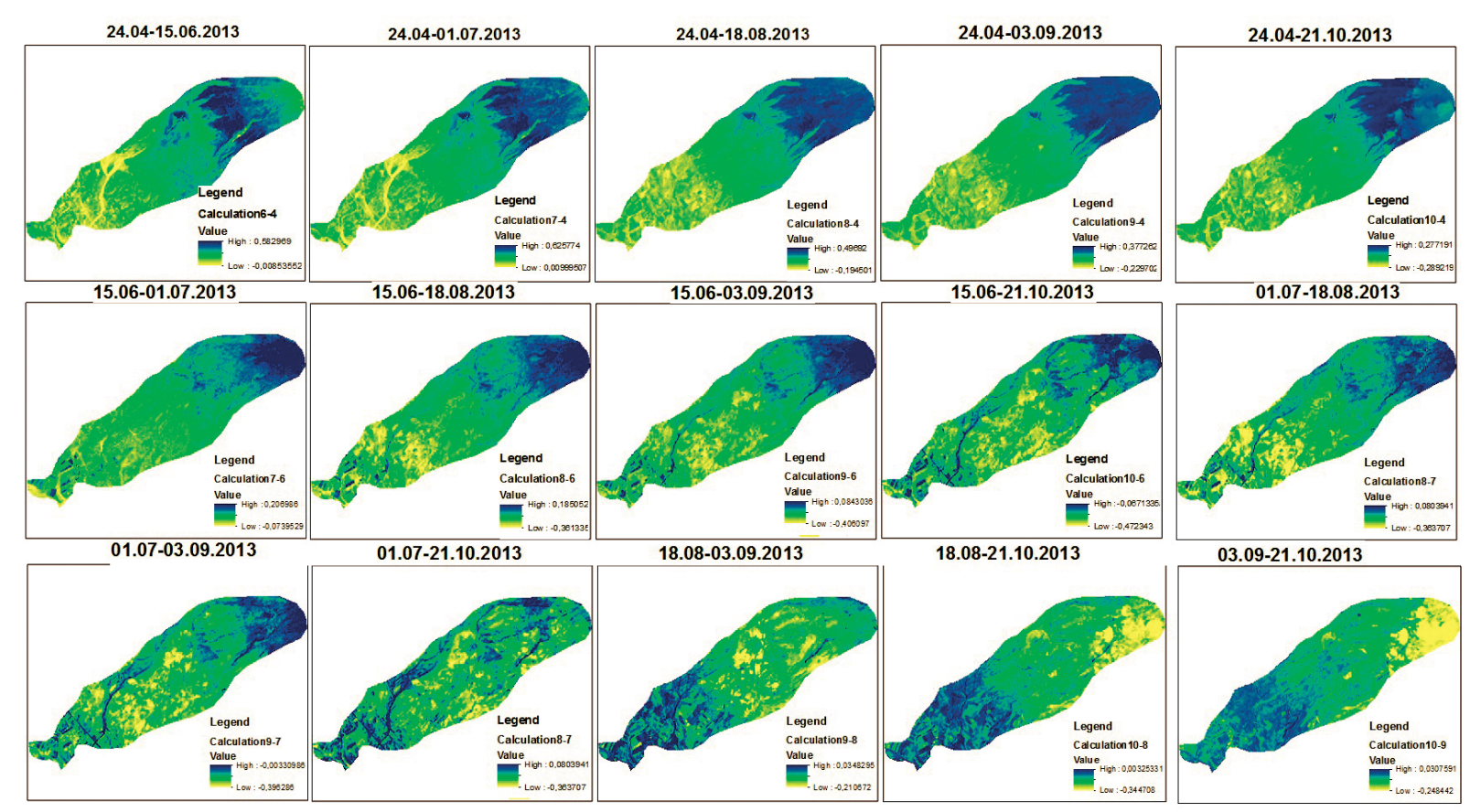

Fig. 2. Differences between NDVI raster maps of southwest slopes in the vegetation period

Similar trends last after July, however by the month of October the biomass decreases almost over the entire area. It is noteworthy, that there are almost no sharp changes on the AugustSeptember NDVIdiff map.

To obtain an objective picture of space and time variations of NDVI values, we made an attempt to investigate relationship (correlation) between the averaged values of NDVI and absolute altitude of a locality through regression equations.

With this end in view, superposition was performed of digital elevation maps of the locality and NDVI for different months in the vegetation period. As a result, a correlation was established of NDVI values for northeast and southwest slopes for April through October 2013 and absolute altitude of the locality.

To derive correlation, in the first turn we brought into compliance the ordinal relations of pixels of NDVI map and digital elevation model. Then, by a Raster to Point command we derived vector point layer corresponding to each pixel and, using data from the database, produced correlation graphs by regression equations.

According to the linear regression equations, the relationship between absolute altitudes of northeast and southwest slopes and NDVI for August indicates presence of positive correlation 
(correlation coefficients are 0.5 and 0.72 , respectively), better pronounced for southwest slopes, i.e. the higher the locality, the higher is NDVI and therefore the biomass.

However, considering nonlinear regression coefficients: 0.53 and 0.75 , respectively, we conclude that the correlation between NDVI and absolute altitude of a locality is nonlinear rather than linear. For instance, NDVI for southeast slopes decreases upward for altitudes of 1800 to 2000 $\mathrm{m}$, then increases up to $2950 \mathrm{~m}$, then decreases again. The maximal biomass is detected at altitudes of 2900-3000 m. NDVI for northeast slopes decreases upward for altitudes of 1800 to $2000 \mathrm{~m}$, then increases up to $2800 \mathrm{~m}$, mildly decreases up to $3000 \mathrm{~m}$ and increases again. The maximal biomass, unlike southwest slopes, is detected at heights of 1750-1850 m. Collation between the obtained NDVI and field research data (Table 1) shows that variations in biomass data obtained on different belts and NDVI agree well.
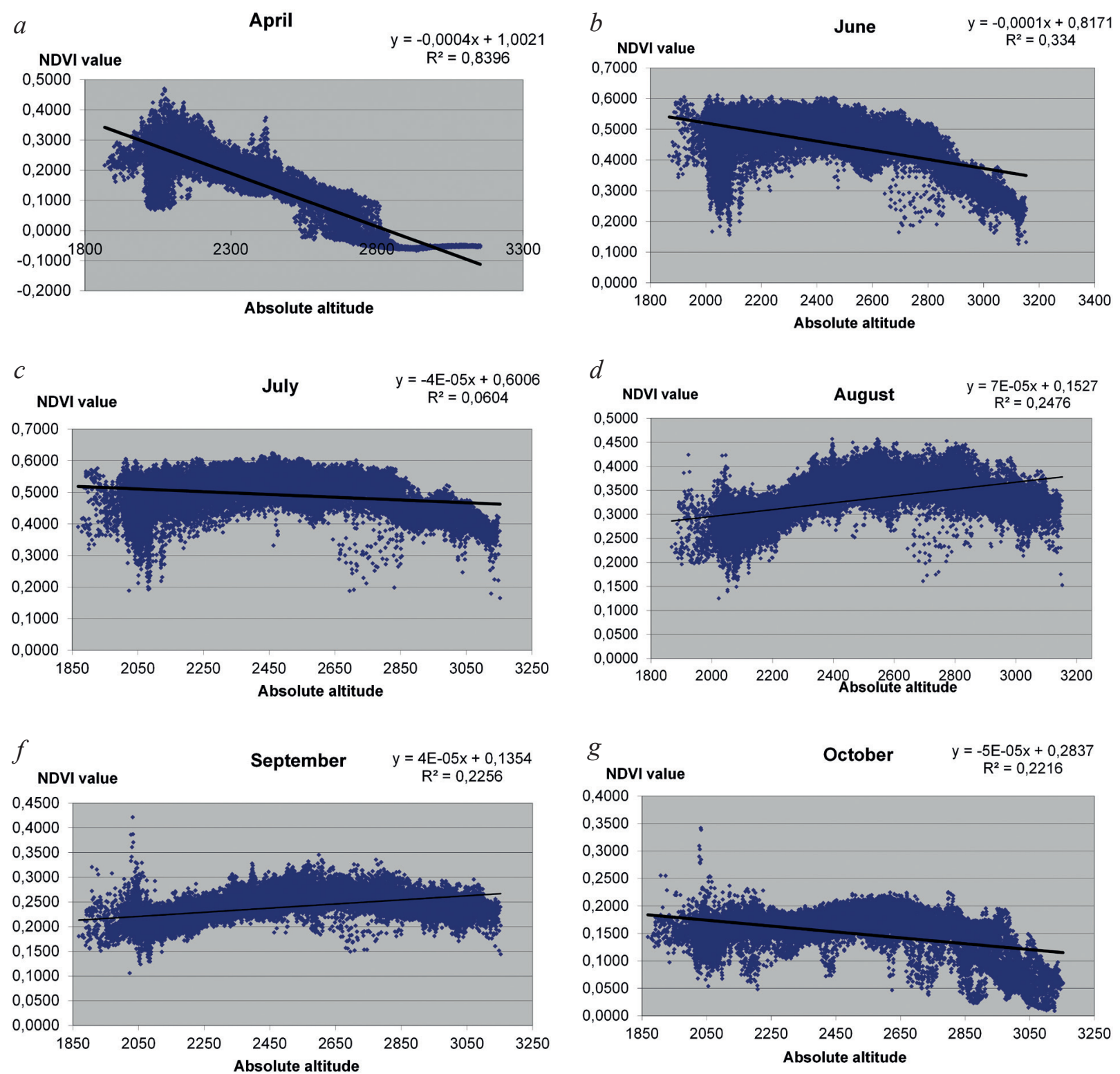

Fig. 3. Relationships of averaged NDVI for southwest slopes and their absolute altitudes by linear regression equation for 2013: April (a), June (b), July (c), August (d), September (f), and October (g). 
As pointed out earlier, we also established the correlation between NDVI for southwest slopes (Syuniq volcanic plateau) and absolute altitude of the locality for each month of the 2013 vegetation period (Fig. 3).

As seen from Fig. 3, the correlation coefficients for different months are quite different. For instance, in April, June, July and October a negative linear correlation is detected with correlation coefficients of $0.84,0.3,0.1$, and 0.2 , respectively, and rather high correlation coefficient attributed only to April. In August and September, linear correlation is positive: 0.3, 0.2, and 0.2, respectively. It is obvious, however, that correlations derived from linear regression equations are either insufficient or almost equal to zero. The analysis demonstrates that a high correlation coefficient (0.615) is derived from nonlinear regression equation.

Finally, we may conclude that high correlation coefficients between NDVI of southwest slopes and absolute altitudes of localities are detected in April and August, while altitude NDVI variation is nonlinear.

\section{Conclusions}

From the obtained results we can conclude the following:

1. NDVI derived from multispectral satellite images allows assessing and investigating peculiarities of space and time variations of biomass of mountain ecosystems.

2. NDVI for south facing slopes is higher than that of north facing slopes in April, October and November, for the rest of the months it is vice versa.

3. The NDVI-based research of different-aspect slopes at 1850-3150 $\mathrm{m}$ indicates that during the vegetation period, the highest biomass is detected on north facing slopes at altitudes of 2300-2400 m, while the lowest on south facing slopes at altitudes of 2000-2100 m.

4. Correlation between NDVI of southwest slopes and absolute altitudes of localities is nonlinear $\left(\mathrm{R}^{2}=0.6\right)$, because the linear correlation gives $\mathrm{R}^{2}$ values of $0.2-0.3$.

5. In the first approach, collation of NDVI obtained from remote sensing data and field research results demonstrates a close relationship between them. However, to achieve higher accuracy, it is essential to obtain and process concurrent field and satellite data.

The obtained results can be used in farming and land management, in particular managing natural grasslands.

\section{References}

1. Aghababian Sh. M., Gornye senokosy i pastbishchy (Mountain hayfields and pastures), Moscow: GISL, 1959,341 p.

2. Ziroyan A. N., Ekologo-bioenergeticheskaya ocenka rastitelnosti Armenni (An ecological and bioenergy assessment of Armenia's vegetation), Yerevan: Lusabac, 2008, 352 p.

3. Kronberg P., Disstancionnoe izuchenie zemli (Remote investigation of the Earth), Moscow: Mir, 1988, 352 p.

4. Maghakian A.K., Rastitelnost Armyanskoi SSR (Vegetation of the Armenian SSR), Moscow: AN SSSR, 1941, $276 \mathrm{p}$.

5. Mezhunts B.Kh., Bioenergeticheskie pokazateli fitocenozov v razlichnix ekologicheskix uslovijax (Bioenergy indices of phytocoenoses under different ecological conditions), Tez. Dokl. Mezd. Konf. Fundamentalnye i prikladnye problemy oxrany okruzayushchei sredy (Proc. Int. Conf. Fundamental and applied problems of environmental protection), Tomsk, 2005, p. 73. 
6. Narinian S.G., Sootnoshenie nadzemnoi I podzemnoi massy rastitelnosti alpijskix kovrov gory Aragac/Armenia/ v svjazi s evolyuciei relefa I genezisom pochv (Correlation of aboveground and underground phytomass of Mt. Aragats alpine carpets. (Armenia) in connection with relief evolution and soil genesis), Probl. Bot., 1966, Vol. 8, pp. 231-245.

7. Trifonova T.A., Mishchenko N.V., Krasnoshchekov A.N., Geoinformatsionnye sistemy I distancionnoe zondirowanie w ekologicheskix issledovanijax (GIS systems and remote sensing in ecological studies), Moscow: Akademicheski Proekt, 2005, 348 p.

8. Belsius L., Weirich F., The use of the Minnaert correction for land-cover classification in mountainous terrain, International Journal of Remote Sensing, 2005, Vol. 26, pp. 3831-3851.

9. Bernstein L.S, Adler-Golden S.M, Sundberg R.L., Validation of the QUick Atmospheric Correction (QUAC) Algorithm for VNIR-SWIR Multi- and Hyperspectral Imager, Proceedings of the SPIE Algorithms and Technologies for Multispectral, Hyperspectral and Ultraspectral Imagery XI, Orlando, 2005, p. 668.

10. Biard F., Lepoutre D., On Line Vegetation Condition Monitoring in Europe: Agri-Quest巴. A Tool That Helps Users Build Information and Value from Remote Sensing, Proceedings of the conference EFITA 2001, Montpellier, 2001, pp. 507-512.

11. Flynn E.S., Dougherty C.T., Wendroth O., Assessment of Pasture Biomass with the Normalized Difference Vegetation Index from Active Ground-Based Sensors, Agronomy Journal, 2008, Vol. 100, pp. 114-121.

12. Freeman K.W., Martin K.L., Teal R.K., Raun W.R., Girma K., Arnall D.B., Mullen R.W. By-Plant Prediction of Corn Forage Biomass and Nitrogen Uptake at Various Growth Stages Using Remote Sensing and Plant Height, Agronomy Journal, 2007, Vol. 99, pp. 530-536.

13. Hadjimitsis D.G., Papadavid G., Agapiou A., Themistocleous K., Hadjimitsis M.G., Retalis A., Atmospheric correction for satellite remotely sensed data intended for agricultural applications: impact on vegetation indices, Nat. Hazards Earth Syst. Sci., 2010, Vol. 10, pp. 89-95.

14. Hatfi J.L., Gitelson A.A., Schepers J.S., Walthall C.L., Application of Spectral Remote Sensing for Agronomic Decisions, Agronomy Journal, 2008, Vol. 100, pp. 117-131.

15. Hunt E.R., Everitt J.H., Ritchie J.C., Applications and Research Using Remote Sensing for Rangeland Management, Photogrammetric Engineering and Remote Sensing, 2003, Vol. 69, pp. 675-694.

16. Kaufman Y., Tanre D., Atmospherically resistant vegetation index (ARVI) for EOS-MODIS, IEEE Transactions on Geoscience and Remote Sensing, 1992, Vol. 30, No. 2, pp. 261-270.

17. Lu D., Mausel P., Batistella M., Moran E., Land-cover binary change detection methods for use in the moist tropical region of the Amazon, International Journal of Remote Sensing, 2005, Vol. 26, No. 1, pp. 101-114.

18. Lusch D.P., Introduction to Environmental Remote Sensing, Michigan: Center for Remote Sensing and GIS, $1999,750 \mathrm{p}$.

19. Mezhunts B.Kh., Britt C.P., Mc Millan S.D., Givens D.I., The distribution of root biomass and energy yields in mountain grasslands in Armenia, Electronic J. Natural Sci., NAS of Armenia. Ecology, 2005, Vol. 1, No. 4. pp. $1-5$

20. Milich L., Weiss E.A., GAC NDVI interannual coefficient of variation (CoV) images: ground truth sampling of the Sahel along north-south transects, International Journal of Remote Sensing, 2000, Vol. 21, No. 2, pp. 235-60.

21. Minamiguchi N., The Application of Geospatial and Disaster Information for Food Insecurity and Agricultural Drought Monitoring and Assessment by the FAO GIEWS and Asia FIVIMS, Proceedings of the Workshop on Reducing Food Insecurity Associated with Natural Disasters in Asia and the Pacific, Bangkok, 2005, pp. $20-21$.

22. Olson K.C., Cochran R.C., Radiometry for Predicting Tallgrass Prairie Biomass Using Regression and Neural Models, Journal of Range Management, 1998, Vol. 51, No. 2, pp. 186-192.

23. Rause J.W., Haas R.H., Schell J.A., Deering D.W., Monitoring vegetation systems in the Great Plains with ERTS, Proceedings of the $3^{\text {rd }}$ ERTS symposium, 1973, Vol. 1, pp. 48-62.

24. CARMAC CS-11/103: Mapping and assessing the community grasslands and developing a grazing scheme, Project report. Yerevan: The Center for Ecological-Noosphere Studies of NAS RA, 2014, 400 p.

25. Serrano L., Filella I., Penuelas J., Remote Sensing of Biomass and Yield of Winter Wheat under Different Nitrogen Supplies, Crop Science, 2000, Vol. 40, No. 3, pp. 723-731.

26. Singh A., Digital change detection techniques using remotely-sensed data, International Journal of Remote Sensing, 1989, Vol. 10, No. 6, pp. 989-1003.

27. Williams D., Goward S., Arvidson T., Landsat: Yesterday, today and tomorrow, Photogrammetric Engineering and Remote Sensing, 2006, Vol. 72, No. 10, pp. 1171-1178.

28. Zhou L., Tucker C.J, Kaufmann R.K, Slayback D., Shabanov N.V., Myneni R.B., Variations in northern vegetation activity inferred from satellite data of vegetation index during 1981-1999, Journal of Geophysical Research, 2001, Vol. 106, pp. 69-83. 


\title{
Оценка пространственно-временных изменений NDVI (биомассы) в горных экосистемах Армении с использованием дистанционных данных
}

\author{
В.С. Мурадян, Ш.Г. Асмарян, А.К. Сагателян \\ Центр эколого-ноосферных исследований НАН РА, Ереван 0025, Армения \\ e-mail:muradyan-asx@rambler.ru
}

\begin{abstract}
Данное исследование растительной биомассы различных территорий горных экосистем Армении было выполнено в вегетационный период 2013 г. Исследование основано на использовании временных рядов нормализованного разностного вегетационного индекса NDVI, поскольку в последнее десятилетие данные NDVI доказанно являются мощным инструментом мониторинга роста биомассы. Индекс NDVI, который можно рассчитать прямо из данных спутников серии Landsat, относится к характеристикам растительного покрова. Это основанное на данных NDVI исследование склонов с разной экспозицией на высоте 1850-3150 м н.у.м. показало, что в период вегетации наибольшая биомасса обнаруживается на северных (2300-2400 м), а наименьшая - на южных склонах (2000-2100 м). Высокие коэффициенты корреляции между значениями индекса NDVI юго-западных склонов и абсолютной высотой местности наблюдаются в апреле и августе, а колебания значений индекса NDVI в зависимости от высоты носят нелинейный характер.
\end{abstract}

Ключевые слова: биомасса, горная экосистема, NDVI, дистанционные данные

Одобрена к печати: 23.10.2015

DOI: $10.21046 / 2070-7401-2016-13-1-49-60$

\section{Литература}

1. Агабабян Ш.М. Горные сенокосы и пастбища. М: Государственное издательство сельскохозяйственной литературы, 1959. $341 \mathrm{c.}$

2. Зироян А. Н. Эколого-биоэнергетическая оценка растительности Армении. Е: Лусабац, 2008. 352 с.

3. Кронберг П. Дисстанционное изучение земли: М: Мир, 1988. 352 с.

4. Магакьян А.К. Растительность Армянской ССР. М.: АН СССР, 1941. 276 с.

5. Межуни Б.Х. Биоэнергетические показатели фитоценозов в различных экологических условиях // Тез. докл. межд. конф. Фундаментальные и прикладные проблемы охраны окружающей среды. Томск, 2005. C. 73.

6. Наринян С.Г. Соотношение надземной и подземной массы растительности альпийских ковров горы Арагац /Армения/ в связи с эволюцией рельефа и генезисом почв // Пробл. Бот. 1966. Т. 8. С. 231-245.

7. Трифонова Т.А., Мищенко Н.В., Краснощеков А.Н. Геоинформационные системы и дистанционное зондирование в экологических исследованиях. М: Академический Проект, 2005. 348 с.

8. Belsius L., Weirich F. The use of the Minnaert correction for land-cover classification in mountainous terrain // International Journal of Remote Sensing. 2005. Vol. 26. P. 3831-3851.

9. Bernstein L.S, Adler-Golden S.M, Sundberg R.L. Validation of the QUick Atmospheric Correction (QUAC) Algorithm for VNIR-SWIR Multi- and Hyperspectral Imagery // Proceedings of the SPIE Algorithms and Technologies for Multispectral, Hyperspectral and Ultraspectral Imagery XI. Orlando, 2005. P. 668.

10. Biard F., Lepoutre D. On Line Vegetation Condition Monitoring in Europe: Agri-Quest ${ }^{\circledR}$. A Tool That Helps Users Build Information and Value from Remote Sensing // Proceedings of the conference EFITA 2001. Montpellier, 2001. P. 507-512.

11. Flynn E.S., Dougherty C.T., Wendroth O. Assessment of Pasture Biomass with the Normalized Difference Vegetation Index from Active Ground-Based Sensors // Agronomy Journal. 2008. Vol. 100. P. 114-121.

12. Freeman K.W., Martin K.L., Teal R.K., Raun W.R., Girma K., Arnall D.B., Mullen R.W. By-Plant Prediction of Corn Forage Biomass and Nitrogen Uptake at Various Growth Stages Using Remote Sensing and Plant Height // Agronomy Journal. 2007. Vol. 99. P. 530-536.

13. Hadjimitsis D.G., Papadavid G., Agapiou A., Themistocleous K., Hadjimitsis M.G., Retalis A. Atmospheric correction for satellite remotely sensed data intended for agricultural applications: impact on vegetation indices // Nat. Hazards Earth Syst. Sci. 2010. Vol. 10. P. 89-95.

14. Hatfi J.L., Gitelson A.A., Schepers J.S., Walthall C.L. Application of Spectral Remote Sensing for Agronomic Decisions // Agronomy Journal. 2008. Vol. 100. P. 117-131.

15. Hunt E.R., Everitt J.H., Ritchie J.C. Applications and Research Using Remote Sensing for Rangeland Management // Photogrammetric Engineering and Remote Sensing. 2003. Vol. 69. P. 675-694.

16. Kaufman Y., Tanre D. Atmospherically resistant vegetation index (ARVI) for EOS-MODIS // IEEE Transactions on Geoscience and Remote Sensing. 1992. Vol. 30. P. 261-270.

17. Lu D., Mausel P., Batistella M., Moran E. Land-cover binary change detection methods for use in the moist tropical region of the Amazon // International Journal of Remote Sensing. 2005. Vol. 26. P. 101-114.

18. Lusch D.P. Introduction to Environmental Remote Sensing: Michigan: Center for Remote Sensing and GIS, 1999. $750 \mathrm{p}$. 
19. Mezhunts B.Kh., Britt C.P., Mc Millan S.D., Givens D.I. The distribution of root biomass and energy yields in mountain grasslands in Armenia // Electronic J. of Natural Sci., NAS of Armenia. Ecology. 2005. Vol. 1. No. 4. P. 1-5.

20. Milich L., Weiss E.A. GAC NDVI interannual coefficient of variation (CoV) images:ground truth sampling of the Sahel along northsouth transects // International J. of Remote Sensing. 2000. Vol. 21. No. 2. P. 235-60.

21. Minamiguchi $N$. The Application of Geospatial and Disaster Information for Food Insecurity and Agricultural Drought Monitoring and Assessment by the FAO GIEWS and Asia FIVIMS // Proceedings of the Workshop on Reducing Food Insecurity Associated with Natural Disasters in Asia and the Pacific. Bangkok. 2005. P. $20-21$.

22. Olson K.C., Cochran R.C. Radiometry for Predicting Tallgrass Prairie Biomass Using Regression and Neural Models // Journal of Range Management. 1998. Vol. 51. P. 186-192.

23. Rause J.W., Haas R.H., Schell J.A., Deering D.W. Monitoring vegetation systems in the Great Plains with ERTS// Proceedings of the $3^{\text {rd }}$ ERTS symposium, 1973. Vol. 1. P. 48-62.

24. CARMAC CS-11/103: Mapping and assessing the community grasslands and developing a grazing scheme. Project report. Yerevan: The Center for Ecological-Noosphere Studies of NAS RA, 2014. 400 p.

25. Serrano L., Filella I., Penuelas J. Remote Sensing of Biomass and Yield of Winter Wheat under Different Nitrogen Supplies // Crop Science. 2000. Vol. 40. P. 723-731.

26. Singh $A$. Digital change detection techniques using remotely-sensed data // International Journal of Remote Sensing. 1989. Vol. 10. P. 989-1003.

27. Williams D., Goward S., Arvidson T. Landsat: Yesterday, today and tomorrow // Photogrammetric Engineering and Remote Sensing. 2006. Vol. 72. P. 1171-1178.

28. Zhou L., Tucker C.J, Kaufmann R.K, Slayback D., Shabanov N.V, Myneni R.B. Variations in northern vegetation activity inferred from satellite data of vegetation index during 1981-1999 // Journal of Geophysical Research. 2001. Vol. 106. P. 69-83. 